\title{
La fundación de Rusaddir y la época púnica
}

\author{
The Foundation of Rusaddir and the Punic Age
}

\author{
Fernando LóPEZ PARDO \\ Publicado por primera vez en A. Bravo Nieto - P. Fernández Uriel (dirs.), Historia \\ de Melilla (=Colección Historia de Melilla 17), Melilla, 2005, 167-189
}

\section{Un hallazgo imprevisto}

En una de las salas que alojan la excelente colección de vasos griegos del Museo Arqueológico Nacional de Madrid, una vitrina alberga un conjunto de figuras de barro cocido con formas animales. En ese grupo exquisito se encuentra una pequeña terracota que representa un delfín sobre las olas que aún conserva intactas unas pinceladas de pintura roja. El reverso, menos cuidado, tiene un asa y debajo un pequeño recipiente para recoger el líquido que entrará en el interior por cinco agujeros y fluirá después por la boca del cetáceo. Ningún letrero indica la procedencia, pero sin lugar a dudas es una pieza hallada en Melilla. ${ }^{1}$ Esta constatación ha sido meramente casual.

En su ya clásico Melilla Prehispánica R. Fernández de Castro señala que fueron remitidas unas ánforas y otras cerámicas al Museo Arqueológico Nacional en 1904 y 1908; el interés por ellas me llevó a encontrar en dicha institución la preceptiva copia realizada con papel carbón de una carta de 1905 remitida al Presidente de la Junta del Puerto pidiendo precisiones sobre las condiciones del hallazgo de las piezas que recién habían ingresado en el Museo. Se enumeran nueve en el escrito, casi todas ellas eran similares a las que se conservan en el Museo de la Ciudad, ánforas, jarras, brazaletes de cobre, etc., menos la que se relaciona en cuarto lugar: "un vaso en forma de delfín", que es el que a continuación se localizó entre las otras figuras de animales expuestas (Fig. 1).

Aunque luego penetraremos en su significado y en el pensamiento de quienes quisieron que alguien fuera al "Más Allá" acompañado por este peculiar recipiente cerámico, en estas primeras líneas incidiremos en los valores simbólicos del hallazgo. El primero de ellos que quisiera destacar es que ha sido hasta ahora una pieza "invisible aunque a la vista de todos" que al fin podemos hacer perceptible en su contexto histórico-arqueológico, algo que no podemos decir de un número indeterminado pero importante de vestigios desaparecidos durante el siglo pasado que jamás podremos rescatar ni analizar. La pieza forma parte destacada también del primer episodio que empezó a desvelar el pasado púnico de la ciudad, el descubrimiento de la necrópolis del Cerro de San Lorenzo, acontecimiento que tuvo la virtud de darle consistencia

1 Sala XVII, vitrina $\mathrm{n}^{\circ}$ 2, temporalmente ocupada por la exposición "Seres híbridos”, que ha desplazado las piezas de la exposición permanente a los depósitos. 


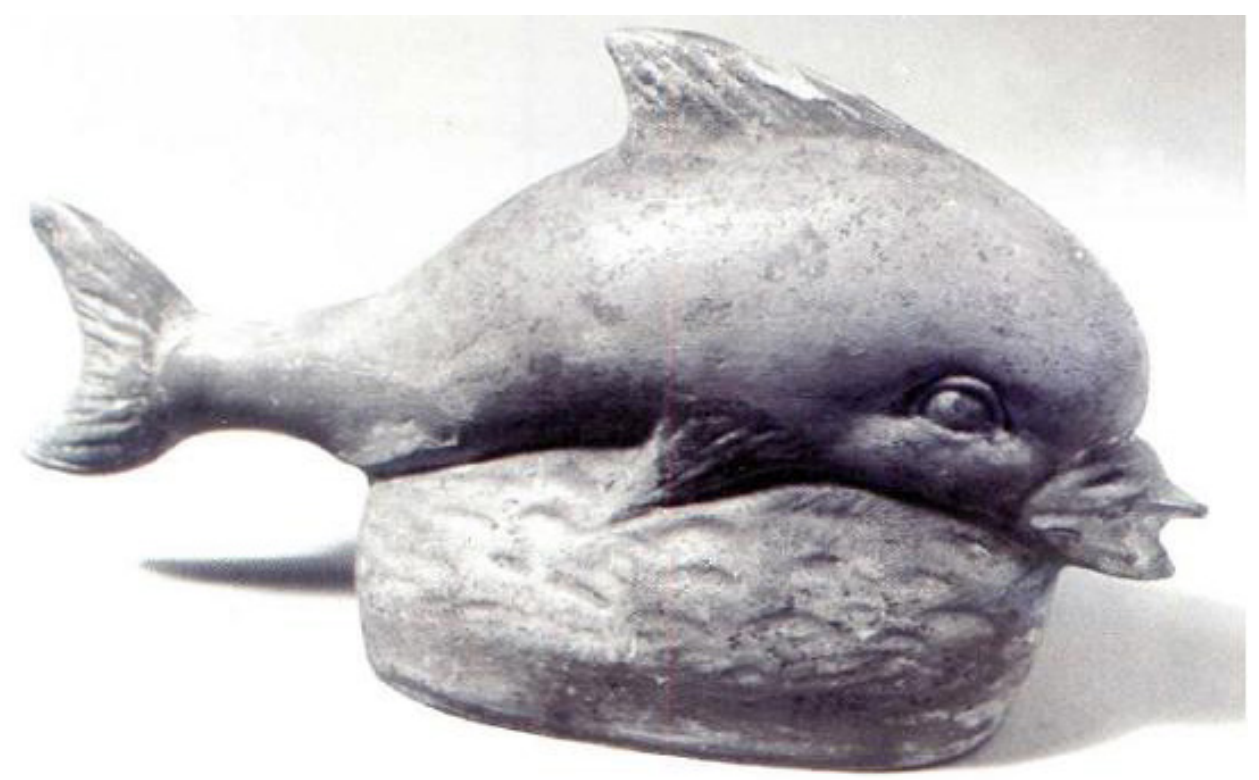

Fig. 1. Vaso plástico en forma de delfín procedente de la necrópolis del Cerro de San Lorenzo. Foto MAN. ninv. 20.279.

material y confirmar una sospecha que se abría paso por el análisis combinado de textos, toponimia y unas rarísimas monedas con leyenda púnica: Rusaddir se encontraba bajo la ciudad de Melilla.

Más que los hallazgos de 1904 a los que corresponde esta pieza, los cuales seguramente no vio Rafael Fernández de Castro, fueron los de 1908 los que despertaron en él "el irrefrenable deseo de proseguir la búsqueda de nuevos motivos de orden histórico o arqueológico", ${ }^{2}$ realizando después excavaciones, estableciendo con pulcritud de notario el registro arqueológico de la necrópolis y procurando el milagro de la conservación de los ajuares que constituyeron el germen del museo ciudadano. Un legado que Miguel Tarradell dio a conocer a la comunidad científica (Fig. 2).

1997, es el año de la formación de un grupo de investigación históricoarqueológica, pero, paradojas del destino, también fue el final de un peculiar ajuste de cuentas con el pasado: tras casi un siglo de esfuerzos por acabar con el Cerro de San Lorenzo, donde aparecieron la terracota, esqueletos con sus ajuares, ánforas usadas a modo de cubierta, etc., se consuma su desaparición con unos últimos desmontes ya estériles desde el punto de vista arqueológico. Se hacía de nuevo intangible un documento escrito sobre la tierra en un pasado remoto que se había vuelto a abrir en 1904 con el inusual hallazgo de una figura de delfín sobre las olas. Por fortuna, un especial empeño de autoridades e investigadores y el interés de la ciudadanía está permitiendo recuperar otros registros arqueológicos de innegable valor en "Plaza de Armas" y "Casa del

2 Fernández de Castro y Pedrera 1945, 224. 


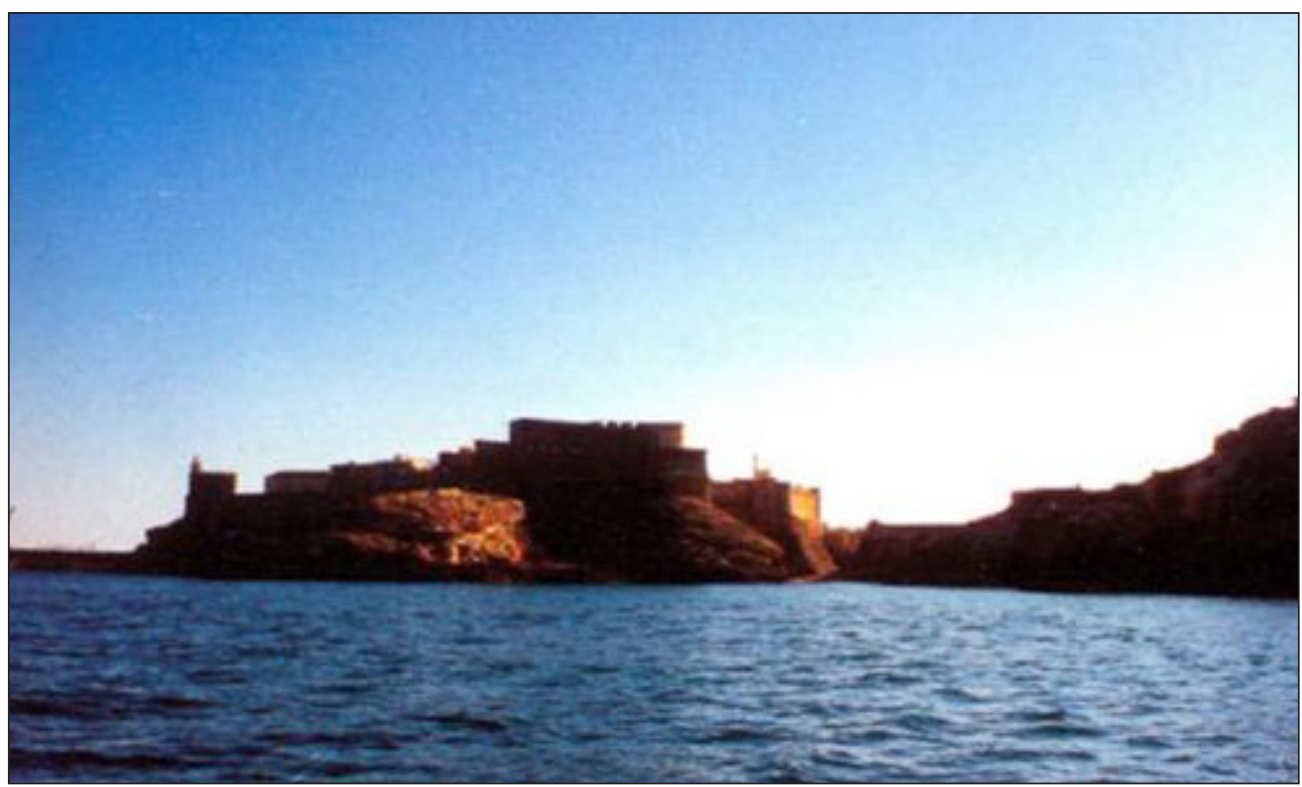

Fig. 2. Vista desde el mar del promontorio de Melilla la Vieja.

Gobernador", en los que se aprecian rastros fenicio-púnicos que nos van a permitir ir leyendo, con la ayuda de viejas referencias literarias y hallazgos numismáticos, el "manuscrito" aún muy fragmentario y con pocas páginas de la Rusaddir púnica.

\section{Pensar un nombre}

\section{a) Significación de Russadir}

Addir es el epíteto que se asignó al cabo Tres Forcas, en estrecha correspondencia con su aspecto imponente. Un calificativo que excede el sentido de "grande" (akra megas), como lo tradujeron algunos autores griegos, pues tiene en lengua fenicia el significado preciso de "poderoso", un adjetivo frecuente para dioses, jefes militares o reyes y elites urbanas en la epigrafía fenicio-púnica. La localidad incrustada en su flanco oriental no podía por menos que arrogarse el distinguido nombre del promontorio protector, el Rus-Addir.

El nombre pertenece a un contexto espacial en el que los promontorios constituyen precisamente los referentes más útiles para los navegantes, dada la escasez de ensenadas y donde, además, éstos también aportan las señas de identidad a los asentamientos que surgen a su amparo. Una especial concentración de localidades con este tipo de denominación en la Antigüedad se registra en Argelia oriental, donde encontramos Rusguniae, Rusubbicari, Rusuccuru, Rusippisir. La sucesión aparentemente se interrumpe en la costa occidental argelina, pero hallamos un eslabón en el asentamiento 
fenicio de la isla de Rachgoun, cuyo nombre actual procede del fenicio-púnico Rusigan. También contamos con fundaciones fenicias o cartaginesas en la costa oriental de Túnez y Sicilia que recurren al nombre del saliente inmediato: Rusicade, Ruspina, Ruspe y Rsmlqrt. En el caso que nos ocupa el apelativo elegido parece una útil indicación o aviso para los navegantes semitas de las características del poderoso cabo para componer sus derrotas, siempre en relación con su contexto próximo, en el cual destaca especialmente de los otros salientes costeros. Sin embargo la denominación no es totalmente expresiva si extendemos nuestra pesquisa a un ámbito más amplio: un portum Rhysaddir menciona Plinio en la costa atlántica de Marruecos. ${ }^{3} \mathrm{Y}$ los nombres de algunos cabos y sus ciudades anejas de Argelia oriental tenían significados equiparables: Rusguniae es por su parte el "Cabo majestuoso", Rusubbicari el "Gran Cabo" y Rusazus un "Cabo fuerte".

Pero las lecturas no son siempre unívocas. La frecuente sacralización de espacios afectó también a los promontorios, así nos encontramos con el cabo de Melqart en Sicilia (Rsmlqrt), otro de idéntico nombre en la costa atlántica marroquí, que vemos después transformado en Punta de Heracles, y un cabo consagrado al dios sanador Eshmun en Túnez. Addir, por otra parte, es un epíteto frecuente de Astarté, Sid, Isis, Tanit y Baal, precisamente Baal Addir ("Seigneur puissant") y Abaddir ("Pierre du Puissant") eran advocaciones o manifestaciones numínicas de Baal Hamón especialmente queridas en el norte de África. Innecesario, pues, recabar más apoyos para confirmar que el cabo y la ciudad se encontraban bajo la protección de una o varias divinidades tutelares. Por su parte Ptolomeo, el admirable geógrafo, transcribe Séstiaria akra ${ }^{4}$ como el cabo que precede a la localidad de Rusaddir, lo que M. Tissot, siguiendo a Movers, considera una corrupción de Sesseth araim (Hebr.) "los seis altares".

La explicación que podemos dar de la permanencia del nombre fenicio-púnico hasta el final de la época romana no tiene que ver con un supuesto desinterés local por el cambio. Hemos de recordar que este nombre constituye un depurado ejemplo de representación metonímica del espacio al que se refiere y como tal entra en la esfera de lo sagrado. Este, a su vez, permanece inmutable pues eliminar un signo de este tipo supone acabar con la realidad mitificada que representa, como muy bien advierte Almudena Hernando. Sobre ello incidiremos más adelante cuando tratemos de la reinvención de los orígenes de la ciudad, baste señalar ahora que el propio nombre del accidente geográfico y su transferencia a la localidad son hechos explicables dentro del complejo sistema cognitivo de los fenicios que, al igual que otros pueblos antiguos, codifica, resalta y tiñe de sacralidad unos pocos segmentos del espacio, los cuales con su reforzada identidad envuelven cualquier realidad próxima, como la localidad que surge al lado del cabo que se hace así partícipe de la misma (Fig. 3).

\footnotetext{
3 Plin. Nat. Hist. V, 9.

4 Ptol. IV, 1.
} 


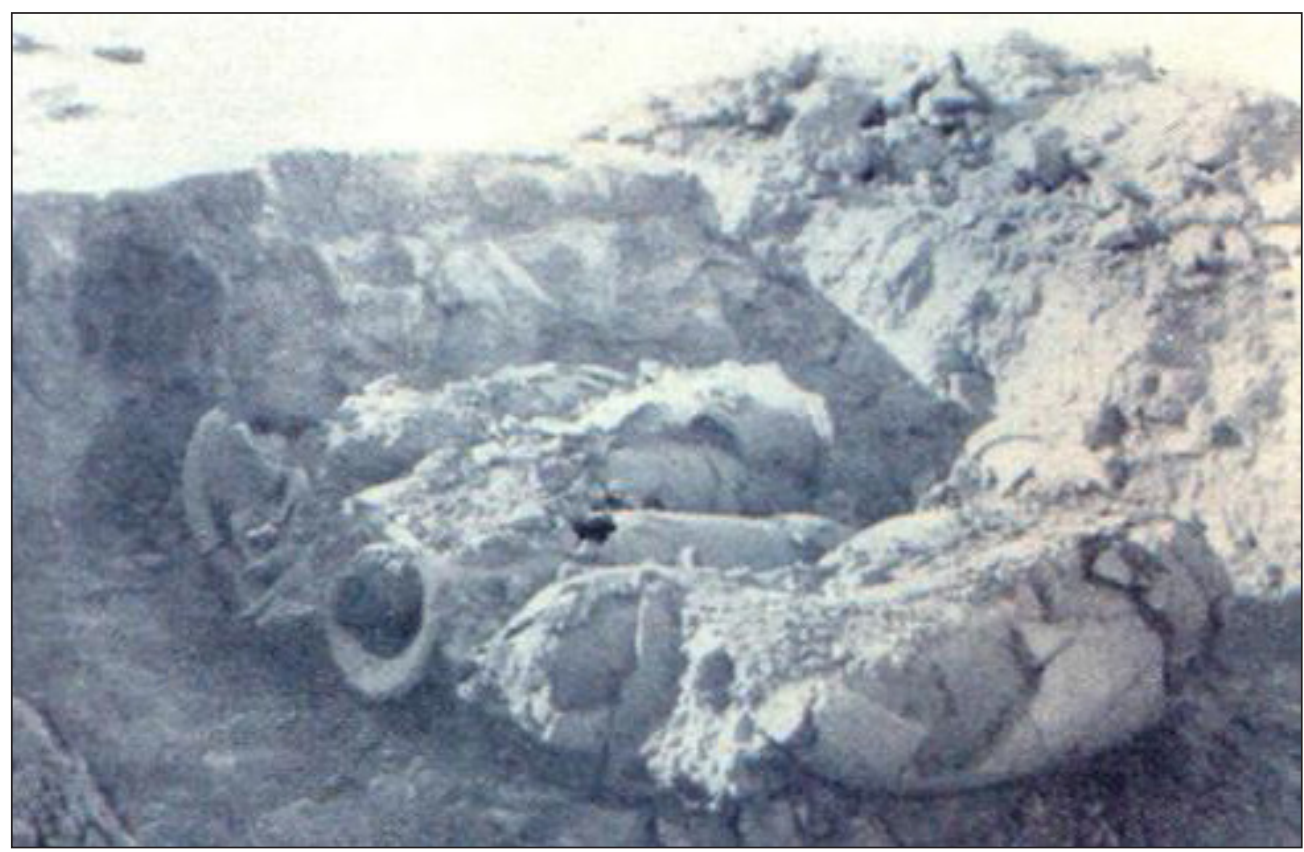

Fig. 3. Excavaciones del Cerro de San Lorenzo. Descubrimiento de ánforas púnicas utilizadas en las sepulturas.

\section{b) Fundar, consagrar: Russadir}

Hasta hace poco tiempo los vestigios más antiguos atribuibles a Rusaddir no rebasaban las postrimerías del s. III a.C., pero un falsario ateniense que se oculta tras el prestigio de Escílax de Carianda, explorador del lejano Indo en el s. VI a.C., nos desvela en su manual marinero la existencia de una ciudad, Akros, más allá de la desembocadura del Siga (uadi Tafna), camino del Estrecho. La lectura del texto sigue siendo problemática, pero todo induce a identificarla con Rusaddir. En la edición más conocida del mismo, K. Müller llama Akra a la isla que se encuentra delante de Siga, considerando poco probable que el apelativo "gran ciudad" que viene a continuación se refiera a una innominada localidad dentro de la isla, dadas sus escasas dimensiones, considerando pues que tal calificativo se refiere a Akros (Rusaddir?) que menciona después. ${ }^{5}$ Aunque la idea es muy sugerente y quisiéramos ver en Rusaddir un gran centro urbano, la reconstrucción es forzada, pues si en todo el capítulo que describe la costa desde Cartago hasta las Columnas no se dice de Cartago o de Útica que son "grandes" ni se utiliza ningún otro adjetivo para otra localidad parece desaconsejable seguir esta lectura. Roget supera las contradicciones trastrocando Akra, polis megale (Akra, gran ciudad) por Akra megale polis (ciudad del Gran Cabo), lo que, creemos,

\footnotetext{
5 Müller 1855, 90.
} 


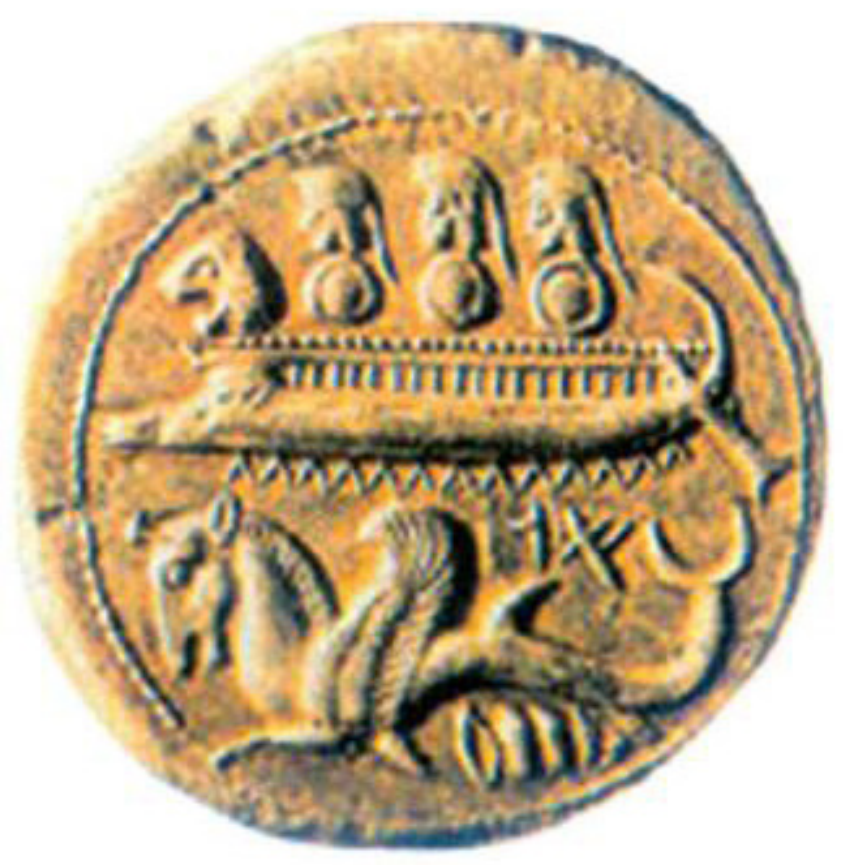

Fig. 4. Moneda fenicia de plata que representa una nave de guerra fenicia. Tiene prótomo y espolón de proa. El mar representado con el símbolo de un monstruo marino. Fechada en torno al siglo VI a.C. Museo Nacional de Beirut.

sería una traducción en griego de Rusaddir. El Pseudo Scylax sigue a lo suyo y continua diciendo: "y esa ciudad se llama Akros, como el golfo que la bordea" (Fig. 4).

Sabemos que el autor ateniense elabora su periplo en la segunda mitad del s. IV a.C. con materiales anteriores, hasta de dos siglos antes, quizás del propio Escílax, como sugiere Peretti, con lo que la falsificación se transforma en actualización y el ocultamiento del nombre del recopilador muta en homenaje al autor del periplo original. Aunque no sabemos de qué estrato cronológico procede la referencia a nuestra localidad, si del siglo VI o del IV a.C., yo preferiría el antiguo en correspondencia con algunos materiales aparecidos en Plaza de Armas fechables entre el último cuarto del s. VI a.C. y primera mitad del V a.C., y una referencia de Hecateo que analizaremos a continuación.

c) «Más allá del promontorio esquinado»

Metagonion sirvió para identificar un promontorio, una región desértica y un pueblo al decir de Estrabón, el conocido geógrafo de época de Augusto, el cual nos da las referencias precisas para su localización, cerca del río Molochath (Muluya). ${ }^{6}$ Es un

6 Str. XVII, 3, 6. 
hito geográfico importante que fue necesario fijar con precisión, por ello el propio autor de Amasia se preocupa en situar en relación con Cartago Nova ya que sirve de límite geográfico y étnico; a partir de allí y hasta las Columnas de Heracles se extiende la región homónima que habitan los artificiosamente llamados metagonitas. ${ }^{7}$ En otra fuente de información más tardía y más precisa de Estrabón, ${ }^{8}$ es el cercano río Muluya el que sirve de frontera entre los maurusios y los masaesilios, lo cual pone de relieve lo fundado de situar en estos parajes el Metagonion.

Es un topónimo inventado por navegantes griegos pero es especialmente antiguo, pues es el que usa el respetado Eratóstenes en el s. IV a.C. para referirse a esta región. Procede de la expresión griega meta to gónion akron (más allá del promontorio esquinado), en la que se denota de alguna manera la existencia de una tierra y pueblo ignotos tras el anguloso accidente, de los que se desconoce hasta su propia identidad. Este escaso conocimiento etnográfico y la expresiva denominación señalan al anguloso cabo Tres Forcas mejor que al cabo del Agua, pues aunque se encuentra junto a la desembocadura del Muluya es muy poco destacable.

En cooperación arcaica con las fuentes de Eratóstenes, Hecateo incluye en su lista de ciudades de Libia una con este nombre, Metagonion, ${ }^{9}$ en la que es necesario ver la urbe que guardaba el cabo anguloso que los griegos reconocían en el Rusaddir. El mismo se corresponde perfectamente con el primer significado de Akros, el nombre que le da el Pseudo Scylax: agudo, puntiagudo. Si el milesio Hecateo no nos confunde, Rusaddir es una localidad de su tiempo, la segunda mitad del s. VI a.C. y es previsible que tuviera mayor antigüedad. Hasta que los trabajos arqueológicos que se vienen realizando en los recintos fortificados no nos reporten una secuencia de estratos arcaicos que no hayan sido borrados por fases posteriores, no podremos tener las primeras evidencias fundacionales. No obstante, si el análisis de los textos ya nos ha aportado indicios que se han visto confirmados por algunos restos materiales en niveles de arrasamiento posteriores, es de esperar que la continuación de los trabajos arqueológicos nos deparará esos primitivos estratos sobre suelo virgen que precisarán o matizarán las características de los orígenes de la ciudad que, salvo sorpresas de última hora, el análisis del contexto permite imaginar.

Cuando en 1953 G. Vuillemot inició sus excavaciones en el islote de Rachgoun (Argelia Occidental) pensaba descubrir una ciudad cartaginesa, sin embargo creyó haber encontrado una escala náutica con una guarnición gaditana; recientemente, algunos colegas han abogado por considerarlo un enclave del imperio tartésico; pero para algunos de nosotros hay evidencias suficientes para valorarlo como una factoría semita poblada a partir de alguna colonia de la región del Estrecho. El mismo horizonte cultural, aunque ligeramente posterior, se aprecia en los enclaves próximos de Mersa Madakh y Les Andalouses y, si nos dirigimos hacia las Columnas de Heracles, también lo hallamos en el recién descubierto poblado de Sidi Drish en la desembocadura del Amekram y Sidi Abdselam del Behar en la del Martil, ambos del s. VII a.C. En todos ellos, vajillas lustradas con engobe rojo, ánforas R1, jarras "Cruz del

7 Str. III, 5, 5; Ptol. IV, 1, 5.

8 Str. XVII, 3, 6.

9 Hecat. Frg. 324. 
Negro", lucernas de uno y dos picos, etc. son idénticas a las de las colonias fenicias del sur de la Península Ibérica y costa atlántica de Marruecos; pertenecen, pues, a lo que se ha denominado Círculo del Estrecho. Las fechas y características de los materiales nos permiten incluirlas en un impulso colonizador distinto al primigenio de Tiro y otras ciudades de Fenicia, pues parecen fruto del empuje y desarrollo de la propia diáspora en el Extremo Occidente. El vínculo permanece durante siglos, incluso cuando los enclaves supervivientes pasaron a la esfera política de Cartago junto a otros que se crearon de nueva planta; salazones, vino y aceite seguirán llegando del Oeste.

La nave imaginaria del Pseudo Scylax que nos ha servido para situar en un horizonte antiguo la fundación de la ciudad, tras dejar Akros (Rusaddir), sorprendentemente cambió de rumbo, se dirigió a la isla de Drinaupa (Albarán) y ya no recaló en la costa africana hasta llegar a una de las columnas de Heracles, Abila (Monte Hacha). Es mimesis del silencio que se adivina tras el topónimo Metagonion, "más allá del promontorio esquinado", y por lo tanto es prueba del desconocimiento de los marinos griegos de la abrupta costa del Rif. Nada más lógico, según me indica Víctor Guerrero Ayuso -autoridad no sólo en arqueología fenicio-púnica sino también en arqueonáutica-, las corrientes y vientos hacen más favorable la derrota hacia el Estrecho por la costa hispana y la de retorno hacia el Mediterráneo Central y Oriente, aunque es ligeramente más favorable la africana, debieron utilizarse ambas, así las naves que recalan en Rusaddir son las naves fenicias que vienen cargadas de Tartessos, Gadir y Lixus. Además lo confirman no sólo los materiales cerámicos sino también las monedas de Gades y Carteia halladas en Melilla.

Fueron, por lo tanto, esas colonias del Círculo del Estrecho las que exploraron y llenaron de colonos los nuevos enclaves de las costas de Marruecos y Argelia occidental, mejor que Cartago, más interesada inicialmente por Sicilia y Cerdeña.

\section{La ciudad proyectada}

Hecateo y Pseudo Scylax coinciden en algo, en utilizar el calificativo de pólis para Metagonion y Akros respectivamente, lo que nos confirma su carácter urbano ya en la segunda mitad del s. VI a.C. Ello presupone el éxito de la elección del lugar o la confluencia de factores favorables que permitieron superar la condición de factoría. Pero, tanto para el autor de Mileto como para el ateniense, igual que para cualquier griego de la época, más que un simple aglomerado de casas, la pólis es una "comunidad política" que se piensa a sí misma como tal y como ciudad, con santuarios y hogares, un espacio ordenado con límites trazados. Más allá de estos rasgos comunes a las póleis mediterráneas, Rusaddir se planifica según la más pura tradición fenicia: un poblado bien protegido en el escarpado promontorio, auténtico salvoconducto para sobrevivir que tenían muy presente los fenicios metropolitanos y los de la diáspora, casi siempre instalados en islotes y salientes rocosos, demasiadas veces inhóspitos o insalubres; necrópolis alejada, separada de la ciudad por el agua, brazo de mar o cauce fluvial, aquí el río de Oro y las marismas que su escaso caudal procuraba. Esta norma religio- 

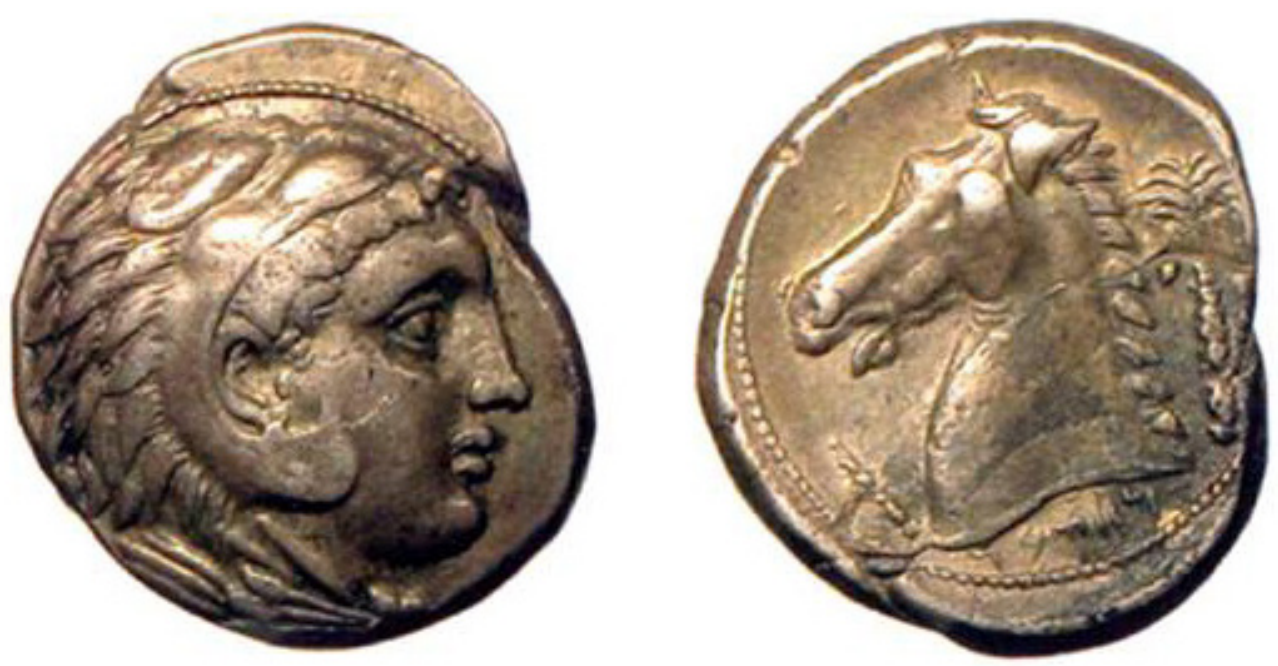

Fig. 5. Moneda púnica con la representación de Heracles Melqart, en su anverso portando la Leonté, símbolo de la divinidad. Reverso, prótomo de caballo y palmera.

sa, que se respeta en la necrópolis del Cerro de San Lorenzo, se abandona en época augustea, los límites ancestralmente trazados de la ciudad servirán ahora para definir el espacio funerario, que se localizará en el cerro contiguo, el Cerro del Cubo (Fig. 5).

Pero, si bien conocemos las necrópolis neopúnica y augustea o mauritana (s. III a.C.-I d.C.), nos faltan las evidencias de la necrópolis más arcaica, quizás ésta se encontrara en el Cerro de Santiago, pues tenemos noticias de que entre 1915 y 1918 aparecieron ánforas cuya tipología se asimila a las del Cerro de San Lorenzo y quizás enterramientos fenicios y púnicos, según recogen Carlos Posac Mon y Jesús Sáez Cazorla. La saturación en las laderas del Cerro de Santiago habría propiciado la ocupación en el s. III a.C. de la colina de San Lorenzo, más lejana y junto al mar.

\section{a) Reinventar el origen}

Las distintas acuñaciones de Rusaddir cuentan siempre en su anverso con una efigie masculina imberbe, con un tocado aparentemente extraño, así el padre Fidel Fita creyó ver "el pellejo y orejas de un elefante", pero, en la penúltima moneda hallada en las excavaciones, la única que he podido ver directamente y no a través de fotos retocadas y dibujos como las otras, me parece evidente que el tocado de inhábil trazo alcanza el mentón del personaje, lo que nos hace decantarnos por la leonté, cabeza de león con la que cubre su cabeza el dios Melqart cuando aparece con atributos de Heracles. Así aparece el dios representado en las monedas de Sidón o las de Lilibeo, y muy especialmente en las acuñaciones gaditanas del s. III a.C., con las que la efigie de Rusaddir parece tener mayores semejanzas.

Como señala Marcel Detienne los pueblos antiguos practicaban el "arte de dispersar los comienzos", ocultando o dejando un espacio muy reducido a las iniciativas 
humanas que procuraron las fundaciones. El origen primero se diluye, después se reinventa, y naturalmente ahora serán de rango divino los seres del comienzo. El acontecimiento inicial que propicia la fundación es en este tipo de relato un hecho dramático, violento las más de las veces, pero necesario: una brutal agresión, una muerte. Pero otras es un mandato oracular o el nacimiento de un linaje entre humano y divino.

Podemos quedarnos simplemente con una visión meramente cultual de la presencia de Heracles/Melqart en Rusaddir, pero la ciudad quizás supo construir a su medida un episodio mítico relacionando su paisaje con el dios de Tiro, de la misma forma que el retorno de Heracles a Tirinto desde la isla que luego acogerá la opulenta ciudad de Gadir (Cádiz), se transformó a lo largo de los siglos en un extenuante recorrido donde no hubo ciudad que dejara de atribuir al héroe alguna peripecia. A este respecto es necesario tener en cuenta que Melqart es príncipe de la colonización, guía esforzado bajo el ropaje heracleo que con sus huestes recorre Libia aniquilando monstruos camino del Jardín de las Hespérides. ${ }^{10}$ También Melqart es el arquégeta de Gadir (Cádiz), el que ordena la fundación de la ciudad y el santuario.

\section{b) Un santuario de tradición púnica}

Aún sigue aflorando en el parapeto del Hornabeque un manantial que encharca el Baluarte Alto de San José, que fue vida para la ciudad antigua y medieval. Ya Ibn Hawkal y AI-Idrisi resaltaron la potencia de su flujo. Esta fuente alimentaba un estanque sagrado, un "ninfeo", de un complejo cultual reordenado en el siglo I a.C. en un ambiente de romanidad propiciado por Juba II, el protegido de Augusto. El estanque semicircular sucede sin duda a otro de tradición púnica, cuya función excede, como veremos más adelante, el papel lustral que habitualmente se asigna a estas estructuras acuáticas: que los fieles lleguen limpios, sin mácula, ante la divinidad (Fig. 6).

Quedarían en el ámbito de las meras hipótesis la atribución del santuario y la organización de los ritos en el complejo cultural si no fuera por el meticuloso y cualificado trabajo arqueológico de Noé Villaverde Vega y el empeño de Javier Martínez Monreal. Así, se ha podido registrar minuciosamente a pocos metros del estanque sagrado un molino diligentemente troceado cuyos restos estaban dispuestos en una fosa en forma de media luna junto a la profunda huella que habían dejado sobre el suelo rocoso los giros de los esclavos molineros. Precisamente, sólo se ha podido recuperar algo más de la mitad de la muela superior, el catillus, que fue, por lógica del proceso de destrucción, la que primero se troceó y se colocó en el fondo, la muela durmiente, meta, se debió trocear y colocar encima, pero los arrasamientos posteriores hicieron desaparecer esa parte. La amortización ritual afectó también al salvado de cereal de la última molienda, al ánfora donde se llevó el grano el último día y a un cuenco. Aquí apreciamos un respeto escrupuloso de las prácticas de amortización ritual, se impide así cometer el sacrilegio de un uso profano del artefacto, lo que podía provocar que la cólera divina se abatiese sobre toda la comunidad y hacer del santuario un lugar

10 Salust. Bel Jug. 17; Schol. ad Apollonius Rhodius IV, 1396-99 a, b. 


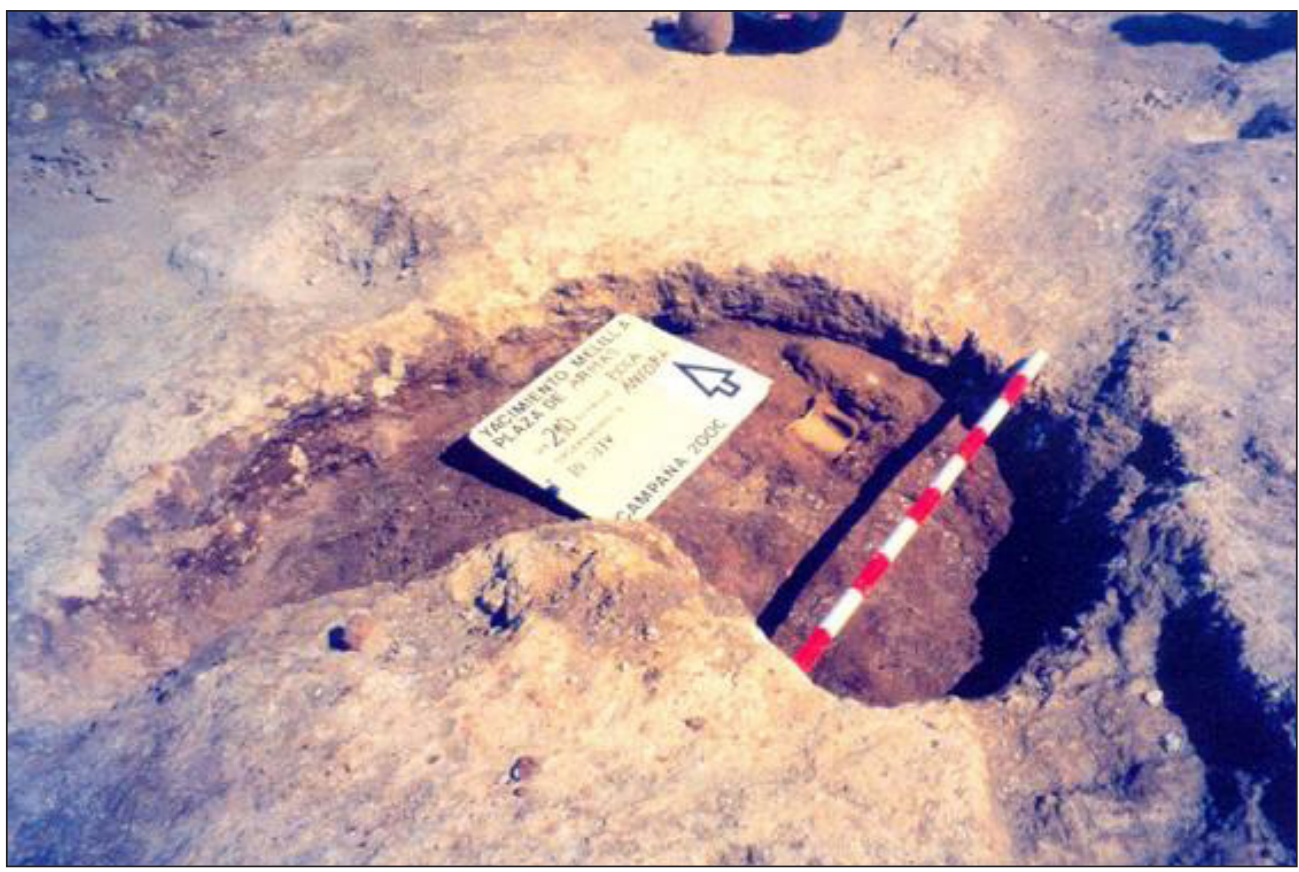

Fig. 6. Fosa de amortización del molino. U.E. 238 con piedras colmatando el fondo y restos del catillus. Foto: Noé Villaverde.

impuro. El soterrado ritual denota un cambio manifiesto de las prácticas de culto de origen fenicio-púnico por otras de influencia claramente romana.

También cereal y salvado han aparecido junto a numerosas ánforas, anforiscos y fuentes de ofrendas rotos intencionadamente y arrojados al interior de dos construcciones subterráneas realizadas en el interior de sendas cavidades, que previamente debían desempeñar la misma función. Se trata, pues, de los Bothro, los depósitos del santuario, utilizados al menos desde el siglo V a.C. hasta el siglo I a.C. Su finalidad era inutilizar sistemáticamente y preservar todo aquello que se ha manipulado en las ceremonias y que por ello pertenece a la diosa. El salvado arrojado a los Bothro era el que quedaba en los cedazos tras cerner la harina, y los granos de cereal hallados son los que permanecieron adheridos a las paredes de las ánforas y anforiscos en los que llegó el grano al templo. Así, el contenido de los depósitos de amortización de los desechos revelan cual era el rito más frecuente en el santuario: la ofrenda de panes o pasteles hechos con harina blanca.

Muy significativa también es la aparición en dichos depósitos de un pequeño exvoto en forma de bebé. Todo cobra sentido: el agua adquiere en este contexto un significado mucho más trascendente, no se trata sólo de un elemento purificador, es fuente de vida, de fecundidad, que en los contextos fenicio-púnicos aparece asociada por norma al culto de Astarté. Ésta es la diosa de todas las manifestaciones de la fertilidad, ya sea de la vegetación, animal o humana. Aquí este significado del agua 
queda más destacado aún, pues ésta surge aparentemente de las profundidades de la tierra; es un fluido de origen infraterrenal, sobrenatural. El escenario astarteano pudo completarse - como en otros casos- con una gruta, quizás la que aún existe bajo la plataforma rocosa, pero de la que no sabemos su tiempo, o la cavidad que debió abrigar la fuente. El complejo cultual de Rusaddir, por estos múltiples y específicos rasgos, se convierte en un depuradísimo ejemplo de santuario astarteano propio de una localidad costera, un tipo de complejo ceremonial sobre el que recientemente han llamado la atención Carlos Gómez Bellard y Pablo Vidal.

No es cuestión de hacer el dossier de los santuarios de Astarté, pero conviene traer a colación unos pocos ejemplos de los que la información es menos sucinta o insegura de lo habitual para darnos cuenta de la fidelidad al patrón seguida por el santuario melillense y para acabar de perfilar sus características: el de Afka (Líbano), vinculado sucesivamente al culto de Astarté-Afrodita-Venus, contaba con una piscina y una serie de canalizaciones que servían para los ritos acuáticos; igualmente el importante santuario de Bostan esh-Sheikh (Líbano) contaba con un gran estanque de agua consagrado a Astarté y Eshmun, y de este lugar de culto proceden estatuillas de niños; el templo de Astarté de Kition (Chipre), por su parte, nos ha librado una lista de pagos al personal del templo donde se menciona un "maestro del agua" en relación con los ritos del templo y sus instalaciones hidráulicas; y el complejo cultual gaditano de Astarté, compuesto de un templo y un santuario excavado en la roca. Sobre algunos de ellos volveremos más tarde.

\section{c) ¿Qué opina la diosa?}

Algo nos ha quedado sin explicar en relación con la diosa: qué significado atribuir a los pasteles de harina blanca horneados en el propio templo.

El profeta Jeremías, ${ }^{11}$ que abominaba de los cultos extranjeros que practicaban en su tiempo los hebreos, especifica que le ofrecen a la "Reina de los cielos" (Astarté) el perfume del incienso quemado y el vino en libación, igual que a otros dioses, pero destaca particularmente la ofrenda de pasteles o tortas, como forma de propiciar la fertilidad. Una práctica que aparece institucionalizada en el santuario de Astarté de Kition (Chipre), donde se señala el pago a "panaderos que han cocido pasteles para la Reina $[\ldots] " .{ }^{12}$

Pero los panes no son sólo obleas para propiciar la benevolencia de la diosa, y menos aún en aquellos santuarios que contaban con estanques abastecidos de agua subterránea, agua de vida, elemento sobrenatural, de alguna manera manifestación de la propia deidad, como el de Rusaddir. Zósimo ${ }^{13}$ nos explica con detalle qué sucedía con estas ofrendas en el santuario de Astarté en Afka (Líbano): los pasteles eran arrojados en el estanque cultual, donde flotaban o no, manifestando así la voluntad de la diosa. Nos encontramos por lo tanto en un dominio oracular, pero nada que ver con las enigmáticas respuestas del oráculo de Apolo en Delfos obtenidas de los eflu-

11 Jer. VII, 18; XLIV, 17-19.

$12 \mathrm{C} / \mathrm{S} \mathrm{I}, 86 \mathrm{~A}-\mathrm{B}$.

13 Zos. I, 58, 2. 

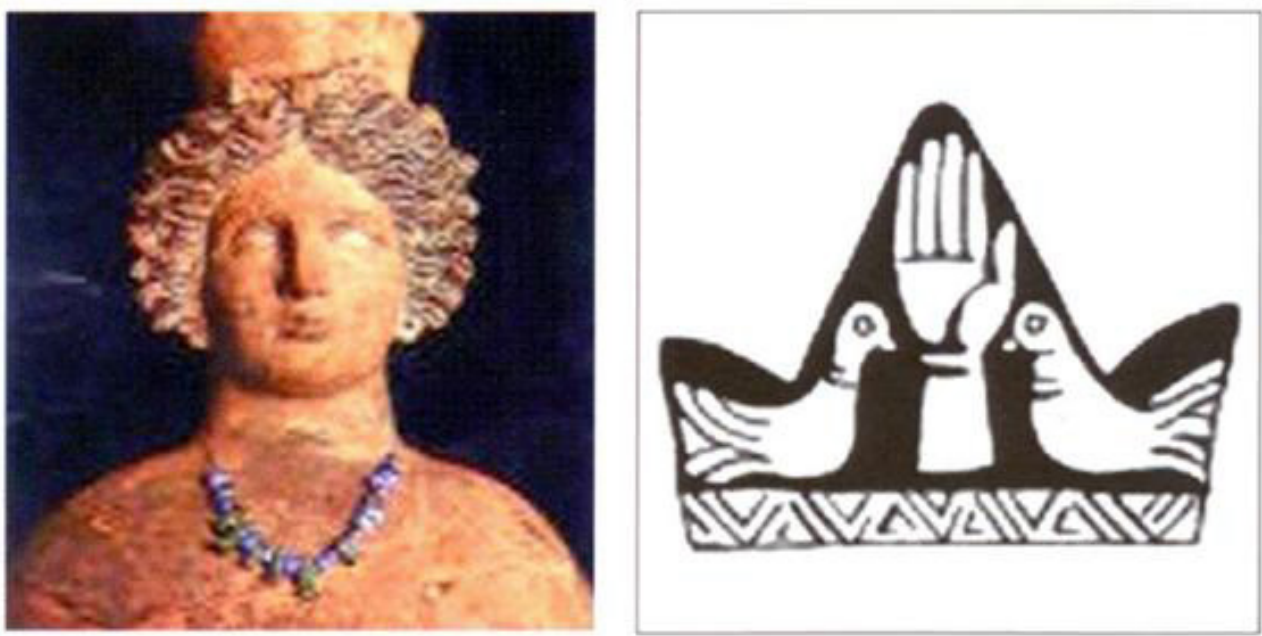

Fig. 7. Representación de la diosa Tanit-Astarté, realizada en terracota policromada procedente de Ibiza. A su lado el símbolo de la diosa: dos palomas enfrentadas.

vios venenosos, o los poco inteligibles agüeros que el pesado sueño de la incubatio procura.

La diosa en su templo de Gades (Cádiz) daba también respuestas oraculares, ${ }^{14}$ y este santuario fue quizás el paradigma de los santuarios de la diosa en Occidente, a cuyo grupo pertenece el de la Plaza de Armas. En Rusaddir apreciamos pues un uso de carácter oracular de los panes de oblación amasados con cereal especialmente malturado en el santuario y arrojados a la fuente de la diosa, de la que se espera una respuesta mediante la acción de su fluido acuoso que surge del interior de la tierra. En fin, el mismo esquema en relación con ese uso del agua advertido por el texto de Zósimo, cuyo rastro se puede seguir en otros muchos templos fenicios, como han apreciado recientemente y muy adecuadamente C. Gómez Bellard y P. Vidal.

La diosa local a la que las mujeres de la ciudad ofrecen exvotos solicitando un feliz embarazo, debió ser objeto de especial veneración por parte de los marinos llegados al puerto, tan cercano al santuario; su llegada sanos y salvos era la ocasión de ofrendas por las gracias alcanzadas, el disfrute de los encantos de las servidoras del templo y la consulta sobre el momento propicio para zarpar y la ruta a seguir, tal y como sabemos que sucedía con los demás santuarios de Astarté situados al borde del mar. No en vano Astarté es diosa celeste y marina, diosa de la fecundidad, diosa de la descendencia. Algo que también parece repetirse de forma constante en sus templos, en íntima relación con los ritos de fertilidad es la existencia de hieródulas destinadas al comercio de sus encantos, con el que llenaban las arcas del santuario. Ello se enmarca en un modelo socialmente muy aceptado, ya que, sacerdotisa, reina o gran dama realizaba con el rey o sacerdote de las ciudades fenicio-púnicas un rito hierogámico,

14 Avien. OM. 314-317. 
una unión sexual solemne a imagen de la propia diosa y su paredro con ocasión de la celebración anual de la resurrección del dios Melqart. Tampoco era infrecuente la unión amatoria prenupcial única u ocasional como rito de paso, siempre realizada en dependencias del templo o en una gruta aneja y siempre con forasteros.

\section{d) Todos con la diosa: palomas, galgo, delfin y, además, monedas}

La especial devoción de los habitantes de Rusaddir a su diosa se aprecia por doquier. La dama que portaba pendientes de oro en forma de paloma y que fueron encontrados en la necrópolis del Cerro de San Lorenzo hacía gala de las aves predilectas de Astarté. El recipiente de libación en forma de perro hallado en otra tumba, remite al otro animal de la diosa, de lo que tenemos numerosas evidencias: con el término $\mathrm{klbm}$ (perros) se denomina a los varones "consagrados" a su culto; ${ }^{15}$ los perros de Astarté eran enterrados en cementerios propios en Ascalón y, en Cádiz, estos mismos animales eran depositados en pozos rituales de las necrópolis.

Por su parte, la efigie del delfín sobre las olas, en el otro recipiente de libación con el que empezábamos este capítulo, es uno de los iconos que escoge Tiro, la ciudadestado responsable de la colonización fenicia, para sus primeras monedas, quizás ya como emblema astarteano en su vertiente de diosa protectora de la navegación, pues los delfines, cetáceos bienhechores, aparecen rodeando a la diosa en monedas sículopúnicas de Rsmlqrt, Lilíbeo y Panormos entre otras, y vemos a Eros cabalgando sobre un delfín junto a Afrodita - una Astarté- en las monedas tardías de la ciudad fenicia de $A k k o$. También simboliza la esperanza de vida ultraterrena, y con este sentido aparecen representados en las estelas de Cartago.

Quizás en relación con este santuario y su renombre regional debamos explicar el aún hermético significado de la abeja en las monedas de la ciudad con leyenda púnica, una iconografía única en Occidente. Si bien Astarté no parece tener una relación acusada con la apicultura, encontramos rastros de la misma en el mundo fenicio arcaico en la Península, donde diosas aladas con cuerpo, quizá de abeja, representadas en bronces y marfiles parecen tener ya una relación con imágenes arcaicas de la griega Melitta, según J. M. Blázquez. Seguramente tenemos en Rusaddir una asimilación de Astarté con la Melitta griega debida en parte a una coincidencia fonética. En un curioso pasaje de Heródoto, ${ }^{16}$ Mylitta es un epíteto dado a la diosa Ishtar de Babilonia, que M. Delcor explica por una permutación de $m$ y de $b$, de tal manera que en realidad el apelativo es Belit, "la dama", nombre con el que se conoce también a la "Señora" de Biblos: B 'lt g $b l$. Precisamente la proclamación del apelativo de la diosa tiene lugar en el santuario babilónico como parte del saludo que efectuaba el fiel una vez obtenidos los favores de una hieródula, una práctica que Heródoto considera reiterativa en los santuarios de tradición fenicia de Chipre, un aspecto cultual que ya hemos adelantado para nuestro santuario. Se puede completar la conexión de los reversos de las monedas de la ciudad con el santuario a través de las dos espigas que enmarcan la abeja, en las que no sería imposible ver una relación con los panes de

15 CIS 1, 86 A-B.

16 Hdt. I, 199. 


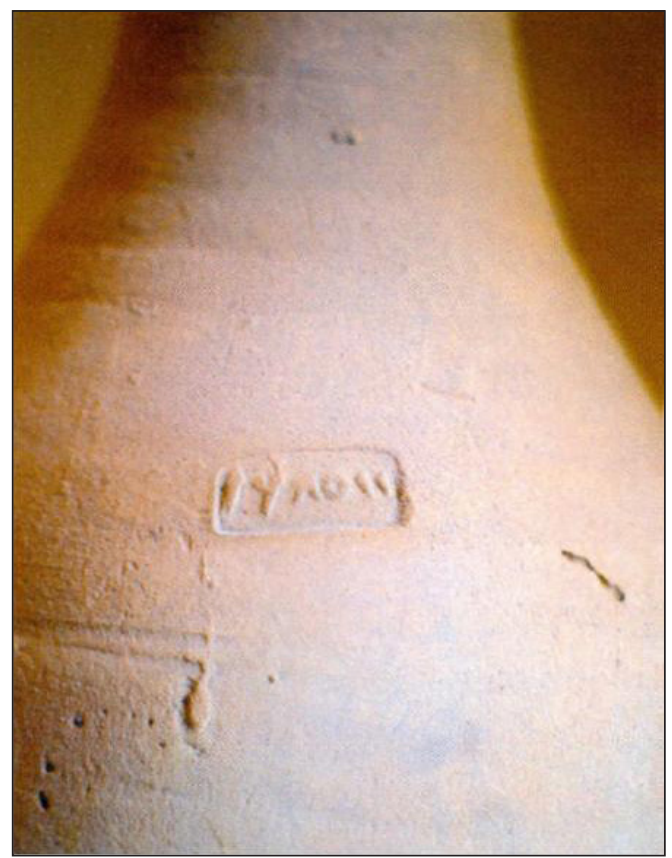

Fig. 8. Ánfora Mañá C 2b con marca púnica. Necrópolis del Cerro de San Lorenzo. Museo de Arqueología e Historia de Melilla.

ofrendas y la fertilidad procurada por la diosa. Por su parte, ha sido Pilar Fernández Uriel quien, de manera sistemática, ha venido observando los incuestionables lazos con deidades griegas y con la apicultura.

\section{Los recursos}

El lector habrá notado que no me he referido a las estampillas con el nombre Bodashtart (En la mano de Astarté) de dos ánforas halladas en el Cerro de San Lorenzo para abundar en la predilección por la diosa de los habitantes de la ciudad. Se trata de un nombre relativamente común en la epigrafía púnica y lo más determinante para no sacar conclusiones apresuradas es que probablemente las ánforas no fueron fabricadas en la localidad, pues las pastas y engobes de éstas y las demás halladas en los sectores excavados son diversos y recuerdan a los de pesquerías de la región del Estrecho, incluso algunas parecen proceder de la bahía de Cádiz, según la opinión acreditada de Pedro Carretero. En una de las dos marcas, bajo las letras se adivinan varios trazos que dibujan la silueta de varias proas de barco con tajamar, lo que nos asegura que es el sello del propietario de una flota pesquera; ello permite hablar de una producción artesanal de salazones de pescado concentrada en pocas manos y capitalizada, pero no sabemos si en el área del Estrecho o en Rusaddir. En fin, hasta que los análisis 


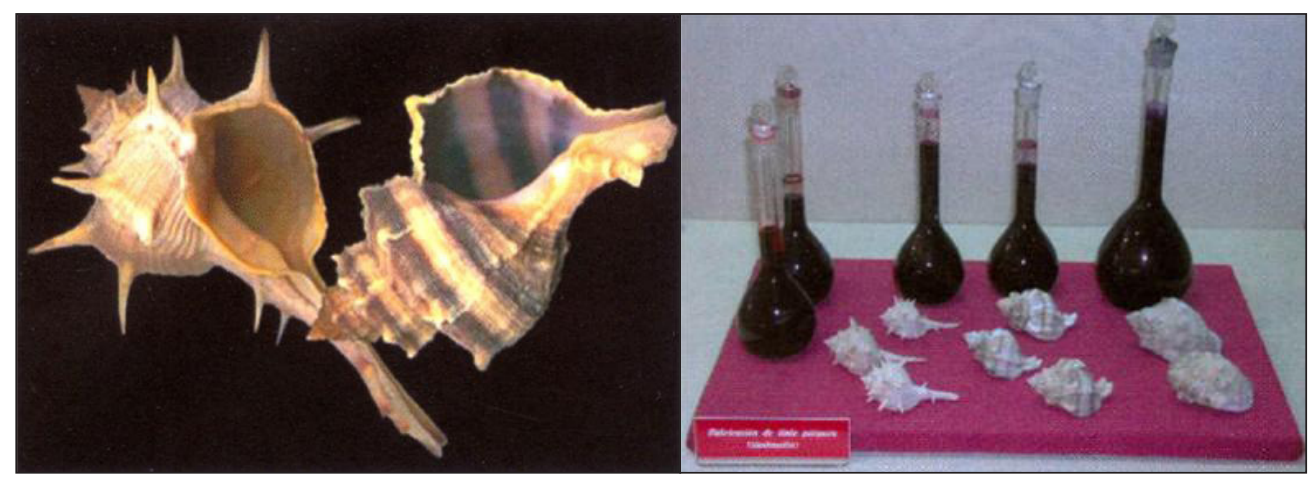

Fig. 9. Los múricespurpúreos (Murex brandaris,Murex truncullusy Purpura haemastoma) de los que se extrae un preciadísimo líquido para fabricar el tinte.

Fig. 10. En la vitrina del Museo de Arqueología e Historia de Melilla se expone este tinte ya elaborado en la propia ciudad.

nos permitan determinar qué recipientes son de fabricación local, debemos hablar de importaciones a partir de los recipientes anforarios bien identificados como procedentes del exterior. Para la época que nos interesa son mayoritarias las T-12 y algunas anteriores como las T-11 provenientes del Círculo del Estrecho, pero contamos con algunas ánforas cartaginesas como una T-S.2.3.2 y una T-6.2.1.1, halladas todas ellas en las excavaciones de Plaza de Armas (Figs. 9 y 10).

Es difícil, por el momento, intentar trazar un panorama productivo y extractivo de la Rusaddir fenicio-púnica hasta que no tengamos resultados de los estudios de los restos de fauna y semillas del yacimiento. La información literaria de la época falta, pero por datos de momentos posteriores se puede asegurar la existencia de una pequeña zona de huertas, la obtención de miel y quizás la recolección de perlas que se señala para época islámica. La producción de bienes derivados de la pesca está por confirmar, pero la captura de peces en el bien resguardado golfo de la Mar Chica, con las salinas de sus proximidades y la documentación de abundantes moluscos de los que obtener la tintura de la púrpura son datos que hemos de tener en cuenta para dirigir la indagación en esta dirección.

Lo mismo sucede respecto a las posibilidades comerciales de la cuenca del Muluya y su impacto en la economía de Rusaddir. El río constituía, en época de Augusto al menos, ${ }^{17}$ la frontera entre los maurusios y los masaesilios, era por ello una zona de intercambios entre la Mauritania Occidental y la Oriental, pero también la depresión fluvial permitía conducir desde ambas vertientes del Alto Atlas hasta el Mediterráneo bienes muy demandados por los fenicios, como marfil, huevos de avestruz, cuernos de órix y pieles. Los animales están representados en la estación rupestre de Ait bou Ichaouen en la vertiente opuesta de la cuenca del Muluya en el Alto Atlas. Tales recursos podían ir a parar a Rusaddir como el enclave fenicio-púnico costero más próximo (Fig. 11).

17 Str. XVII, 3, 6. 


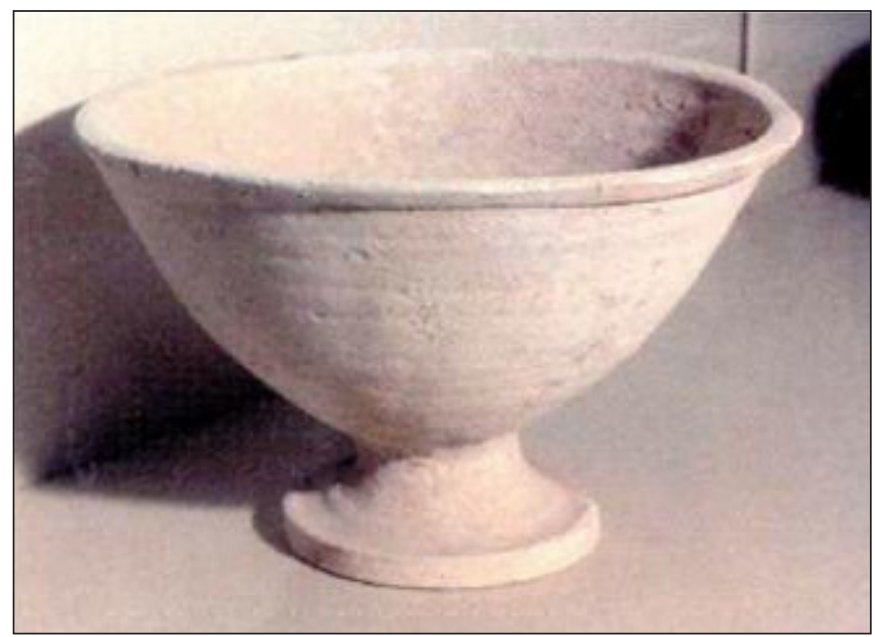

Fig. 11. Copa púnica con peana y borde abierto. Museo de Arqueología e Historia de Melilla.

Su importancia como puerto y escala náutica era evidente y a ella debía parte de su prosperidad, como queda subrayado desde las referencias más antiguas (s. VI-IV a.C.) hasta en autores de época romana como Plinio el Viejo, ${ }^{18}$ lo que llevaba aparejado un cierto carácter estratégico y el interés de algunos estados hegemónicos por ejercer algún control sobre el enclave.

\section{En la esfera de Cartago}

El Pseudo Scylax después de describirnos la costa de Libya y antes de referir lo que hay más allá de las Columnas de Heracles concluye afirmando que todas las ciudades y factorías que enumera desde La Syrte hasta el Estrecho pertenecen a los cartagineses. ${ }^{19}$ Según podemos colegir del texto, Rusaddir se encuentra en la esfera de influencia de Cartago antes del último tercio del s. IV a.C. y el puerto ha adquirido un especial relieve, desde el punto de vista estratégico, para la metrópoli púnica dada su creciente presencia en el Extremo Occidente. Se trata de una información de especial interés para los nautas griegos; se les está señalando que, a diferencia de la costa entre Cartago y Egipto, donde hay asentamientos griegos, en ésta no se localiza ninguno.

La información también hay que ponerla en relación con la prohibición para Roma y sus aliados helenos de navegar y de recalar en puertos de la costa norteafricana desde el Kalón Akrotérion, conocido por los cartagineses como Cabo de Eshmun ( $R$ "ss'mn, cabo Sidi Alí el-Mekki, antes cabo Farina, Túnez), hasta el Estrecho. Esta interdicción se acuerda en el primer tratado romano-cartaginés de finales del s. VI

18 Plin. Nat. Hist. V, 18, 5.

19 Müller 1855, 111. 


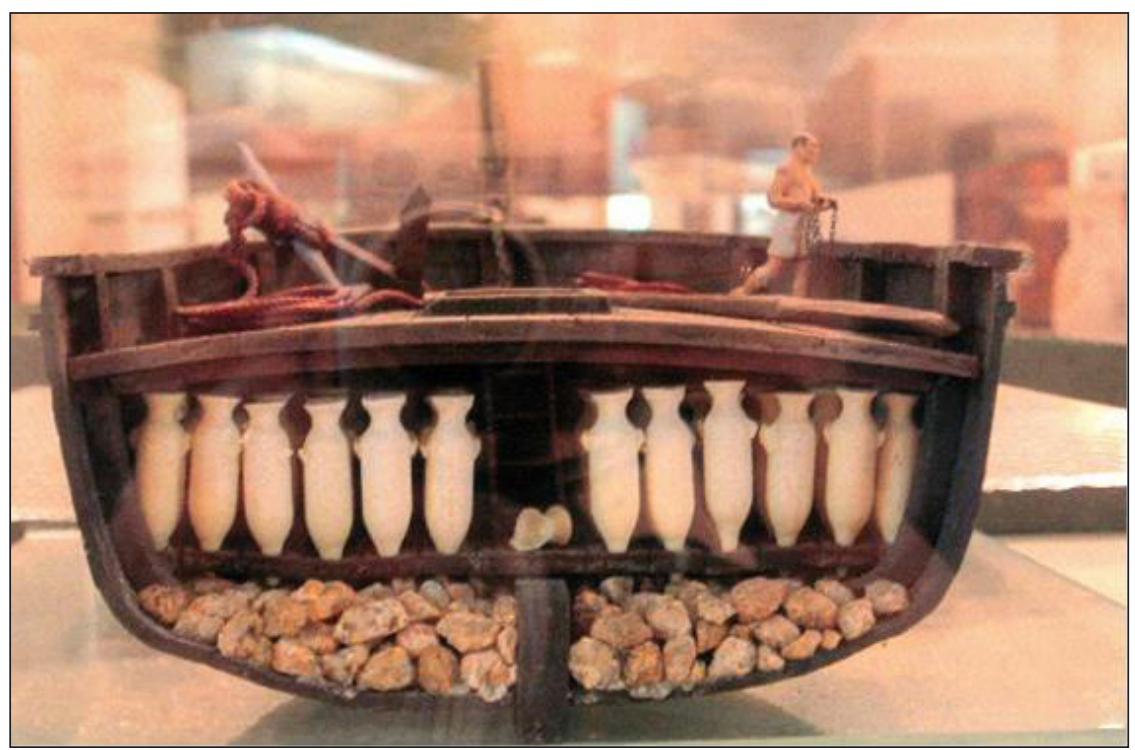

Fig. 12. Representación idealizada de un barco mercante cartaginés (gaulós). Se caracteriza por su alto cabotaje. Popa y proa están levantadas. Su fuerza motriz dependía de sus velas, tenían una gran capacidad y podían alcanzar una velocidad de cinco nudos. Museo de Arqueología e Historia de Melilla.

a.C. y se reitera de nuevo en el segundo, de mediados del s. IV a.C. ${ }^{20}$ Ya estamos lejos del tiempo en que la libertad de navegación y comercio en aguas del Mediterráneo era una realidad, de tal manera que este tipo de conocimiento se convirtió en totalmente necesario para los barcos mercantes (Fig. 12).

\section{El final de una época: el barco se hunde}

En 1981, un dragado realizado en el puerto sacó a la luz uno de los conjuntos de monedas púnicas más cuantiosos que se conocen, varios miles, muchas de las cuales pasaron a manos particulares y cuya dispersión está así asegurada. El hallazgo es prueba del hundimiento de un barco a finales del s. III a.C. destinado a aprovisionar de numerario a distintas guarniciones cartaginesas en el contexto de Segunda Guerra Púnica. Según Carmen Alfaro, la cronología de las monedas de cobre, abrumadoramente mayoritarias, se fija entre 221-210 a.C. aunque existe una presencia testimonial de otras monedas púnicas de Sicilia del s. IV a.C., de Cerdeña de la primera mitad del s. III a.C. y cartaginesas anteriores al citado conflicto bélico (Figs. 13 y 14).

Parece seguro que la nave procedía de la misma Cartago donde cargó tan importante cantidad de monedas, que tienen una proporción de plomo muy elevada, lo que se

20 Pol. XI, 124. 


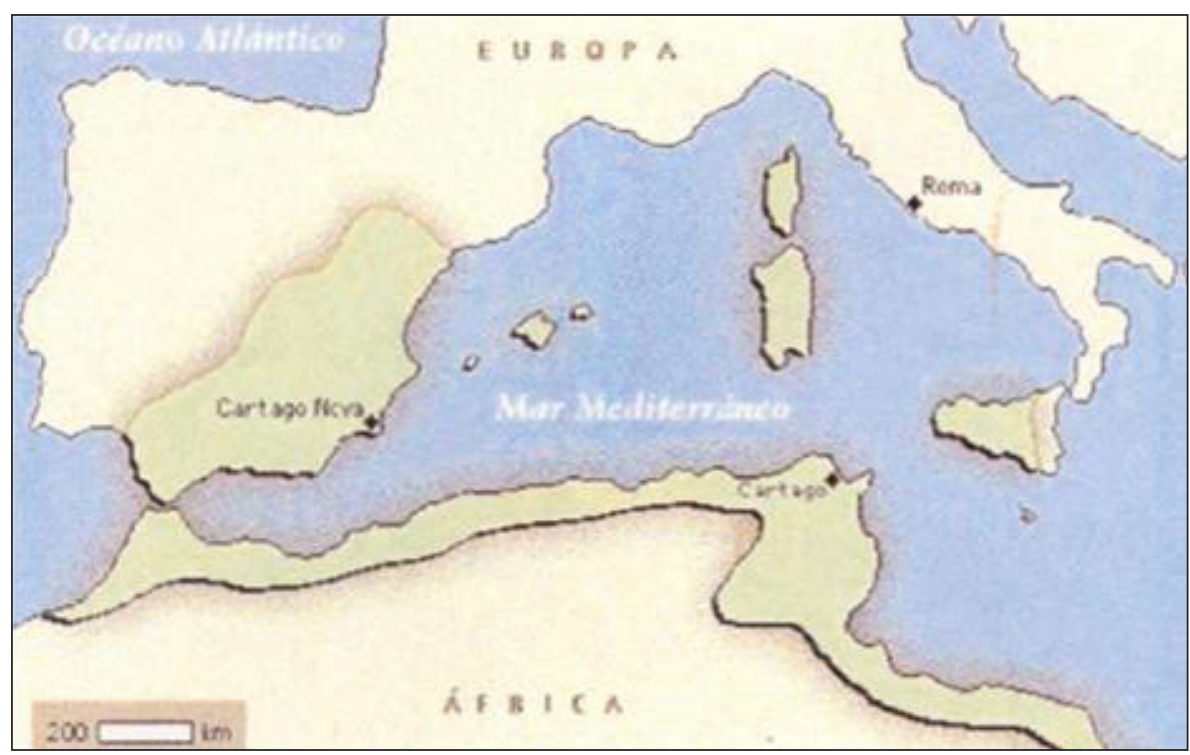

Fig. 13. Mapa del imperio cartaginés.

considera característico de la metrópoli centromediterránea durante las hostilidades. El origen melillense de las emisiones, unas seis, se puede suponer extremadamente improbable pues ello obligaría a imaginar que tan abultadas cantidades de numerario fueron almacenadas durante varios años antes de ser distribuidas entre los mercenarios a los que estaban destinadas.

Como muy bien ha apuntado E. Gozalbes Cravioto el cargamento monetal iba destinado a pagar a tropas mercenarias acantonadas en esta zona de Melilla o en las sucesivas escalas de navegación del norte de África en dirección al estrecho de Gibraltar, durante los años del conflicto bélico. Carmen Alfaro asume esta explicación y considera menos probable que este cargamento fuera destinado a Hispania, bien abastecida de acuñaciones realizadas sobre el terreno por los generales cartagineses hasta el 209 a.C. fecha de la caída de Cartago Nova.

Por la posición de la draga, cerca de la dársena más próxima al extremo del peñasco rocoso de la Ciudad Vieja, da la impresión que la nave de la armada cartaginesa se hundió justo al salir del puerto y perder la protección del promontorio. En Rusaddir había hecho una escala y parece por ello que se dirigía hacia el Estrecho. El episodio se enmarca en un contexto histórico preciso que nos es conocido por Polibio y Tito Livio y sobre el que el hallazgo melillense arroja cierta luz. Al comienzo de la guerra Aníbal había dispuesto que milicianos del norte de África, a los que Polibio llama metagonitas ${ }^{21}$ y Livio númidas y mauri, ${ }^{22}$ aseguraran la zona de Hispania bajo el mando de su hermano Asdrúbal, mientras, reclutó en los "oppida" hispanos gente ar-

21 Pol. III, 33, 8-13.

22 Liv. XXI, 22, 3. 


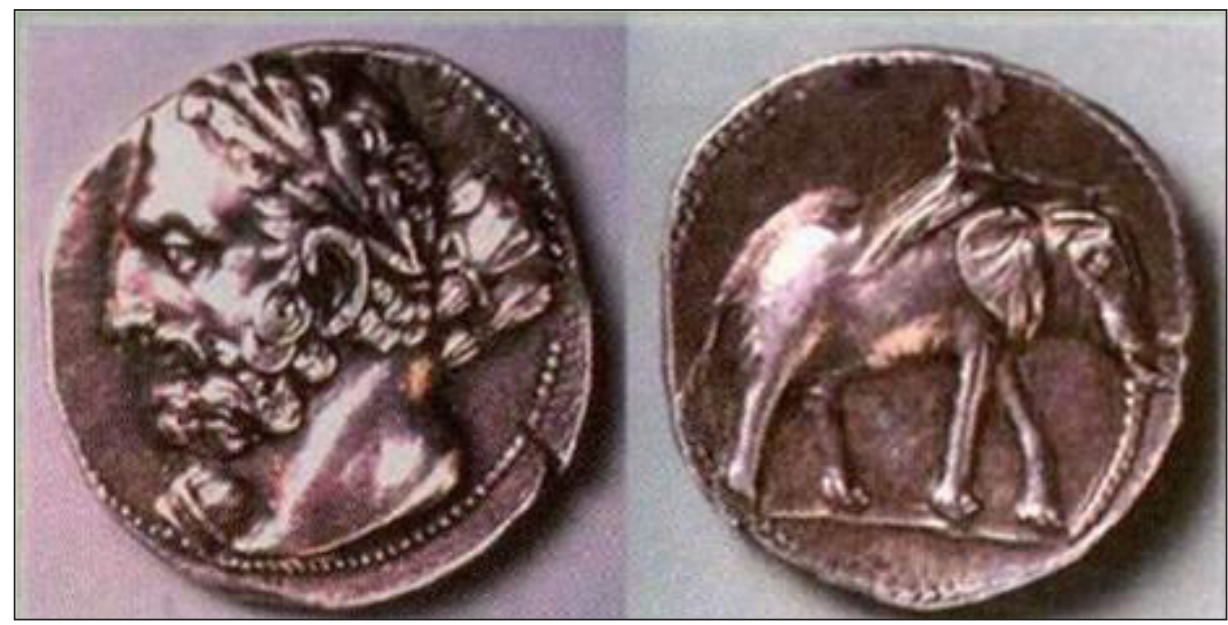

Fig. 14. Moneda con la efigie de Asdrúbal en el anverso, en el reverso el elefante.

mada entre los tartesios, mastienos, etc. para proteger enclaves norteafricanos, entre los que se encuentran los comprendidos entre Rusaddir y el Estrecho, el país de los mauri, el país de los metagonitas.

A pesar de la participación de Rusaddir en el largo conflicto que enfrentó a Cartago con Roma, no llegó a compartir el trágico destino de Cartago, arrasada en el año 146 a.C. Aunque no conocemos el estatuto del que gozó después de perder la dependencia de la metrópoli centromediterránea, es al menos evidente que su situación económica no decayó, se acentuó su diversidad cultural aunque mantuvo durante largo tiempo sus tradiciones púnicas. Todavía en los siglos II y I a.C., algunas personas grababan su nombre o inicial con signos púnicos mientras otras lo hacían ya con trazos latinos. Incluso una de ellas, bnn__ 'según Luis A. Ruiz es quizás un mauritano de cultura púnica, pues su nombre no ha sido atestiguado hasta ahora en la epigrafía semita y recuerda, por el contrario, nombres étnicos y de localidades del interior del país.

\section{En fin}

Estamos lejos aún de poder trazar con pulso firme la historia de los orígenes. Quizás sea mejor así, por ahora, pues la empecinada búsqueda facilita el hallazgo de otros segmentos. No han faltado, pues, viajes por mar, escudriñar y descubrir en los museos lo que se había vuelto invisible, atisbar a los fundadores impelidos por el viento de poniente, seguir los pasos del oekistés fenicio que, secundando un mandato divino, planifica aquí el caserío, allí los santuarios, más allá del río la ciudad de los muertos, en fin, hallar un santuario que agoniza para alumbrar otro, después otro y después otro, apuntar la mántica de la diosa y, en resumen, desvelar algo de la forma de pensar y sentir de aquellos que fundaron la ciudad donde nacimos o vivimos. 


\section{Bibliografía}

Alfaro Asins, C. (1993): "Lote de monedas cartaginesas procedentes del dragado del puerto de Melilla", Numisma 232, 9-46.

Aoftizzer, J. - Jongellng, K. (1995): Dictionary of the North-West Semitic Inscriptions, Leiden.

BARrio, C. (1998): "La numismática y Melilla", Aldaba 30, 193-229.

Bonnet, C. (1996): Astarté. Dossier documentaire et perspectives historiques, Roma.

Coltelloni-Tranoy, M. (1997): Le royaume de Mauretanie sous Juba II et Ptolémée, Paris.

Desanges, J. (1978): Recherches sur l'activité des Méditerranéens aux confins de l'Afrique (VIe siècle avant J.-C. - IVe siècle aprés J.-C.), Roma.

Detienne, M. (2001): Apolo con el cuchillo en la mano, Madrid.

Fernández de Castro y Pedrera, R.

(1945): Melilla prehispánica, Madrid.

(1950): "Las necrópolis púnica y romana de Melilla", África 102, 7-11 (=Aldaba 9, 1987, 127-136).

FERNÁNDEZ URIEL, P.

(2000): "Espacios y elementos de la arqueología melillense: el posible ninfeo de Plaza de Armas: su significado", Akros 1, 28-35.

(1998): "Melilla en el comercio del Mediterráneo: miel, sal y púrpura", Aldaba 30, 53-87.

Gómez Bellard, C. - Vidal González, P. (2000): "Las cuevas-santuario fenicio-púnicas y la navegación en el Mediterráneo", [en] Santuarios fenicio-púnicos en Iberia y su influencia en los cultos indigenas», XIV Jornadas de Arqueología fenicio-púnica (Eivissa, 1999), (=Treballs del Museu Arqueológic d'Eivissa i Formentera 46), Eivissa, 103-145.

Gozalbes Cravioto, E.

(1987): "Economía de la ciudad antigua de Rusaddir", Aldaba 5, 97-120.

(1991): La ciudad antigua de Rusadir. Aportaciones a la historia de Melilla en la Antigüedad, Melilla.

Hernando, A. (2002): Arqueología de la identidad, Madrid.

LIPINSKI, E.

(1995): Dieux et déesses de l'univers phénicien et punique, Leuven.

(1994): "Sites phénico-puniques de la côte algérienne", REPPAL 7-8, 287-324.

LÓPEZ PARDo, F.

(2000): El empeño de Heracles (La exploración del Atlántico en la Antigüedad), Madrid.

(1996): "Los enclaves fenicios en el África noroccidental: del modelo de las escalas náuticas al de colonización con implicaciones productivas", Gerión 14, 251-288.

(1998): "Rusaddir, de la memoria literaria a la realidad histórica de la expansión fenicio-púnica en Occidente”, Aldaba 30, 1998, 35-52. 
López Pardo, F. - Suárez Padilla, J. (2002): “Traslados de población entre el Norte de África y el sur de la Península Ibérica en los contextos coloniales fenicio y púnico", Gerión 20, 113-152.

MüLlER, K. (1855): Geographi graeci minores. E codicibus recognovit, prolegomenis, annotatione, indicibus instruxit, tabulis aeri incisis illustravit, Paris.

Ponsich, M. (1992): "Rusaddir", [en] Dictionnaire de la Civilisation Phénicienne et Punique, Paris, 379.

Posac Mon, C. (1987): "Las perspectivas arqueológicas de Melilla", Aldaba 9, 121126.

Ruiz Cabrero, L. A. (1998): "Dos graffiti púnicos de Melilla (antigua Rusaddir-España)", SEAp 17, 55-65.

Sáez Cazorla, J. (1988): "Atlas arqueológico de Melilla", Trápana, Revista de la Asociación de Estudios Melillenses 2, s.p.

TARRAdell, M. (1954): "La necrópolis púnico-mauritana del Cerro de San Lorenzo, en Melilla", [en] I Congreso Arqueológico del Marruecos Español, Tetuán, junio, 1953, Tetuán, 253-299.

VÁzquez Hoys, A. (1998): “En las manos de Astarté, la abrasadora”, Aldaba 30, 89140.

Vuillemot, G.

(1955): "La nécropole punique du phare dans 1'¡le Rachgoun (Oran)", Libyca 3, 7-76.

(1965): Reconnaissances aux échelles puniques d'Oranie, Autum. 